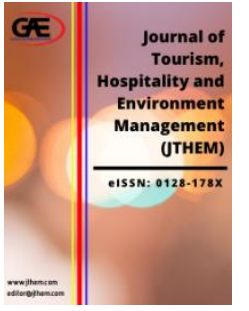

\author{
JOURNAL OF TOURISM, \\ HOSPITALITY AND \\ ENVIRONMENT MANAGEMENT \\ (JTHEM) \\ WWW.jthem.com
}

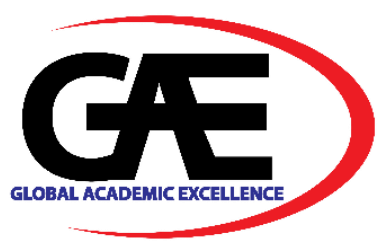

\title{
IMPACT OF AIRBNB ON PHILIPPINE ACCOMMODATION SECTOR: A QUANTITATIVE APPROACH
}

\author{
Mary Vida L. Tumbali ${ }^{1 *}$
}

1 Ph.D. Commerce Candidate, University of Santo Tomas, Graduate School, Philippines

Dept. of Tourism and Hospitality Management, part-time Professor, University of the East, Manila Philippines

Email: maryvidat@gmail.com/maryvida.tumbali.gs@ust.edu.ph

* Corresponding Author

\section{Article Info:}

\section{Article history:}

Received date: 13.10 .2020

Revised date: 25.10 .2020

Accepted date: 01.11.2020

Published date: 02.12.2020

\section{To cite this document:}

Tumbali, M. V. L. (2020). Impact of Airbnb on Philippine Accommodation Sector: A Quantitative Approach. Journal of Tourism, Hospitality and Environment Management, 5 (21), 74 88.

DOI: $10.35631 / \mathrm{JTHEM} .521005$.

This work is licensed under $\underline{\mathrm{CC} B Y} 4.0$

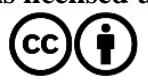

\begin{abstract}
:
The study aimed at scrutinizing the impact of Airbnb on the Philippine hotel accommodation sector with regards to occupancy rates and the number of tourist arrivals. The more extensive point was to make a functional contribution to the current discussions and issues around the sharing accommodation, in particular Airbnb platform, from an ethnically diverse country standpoint. This study used a quantitative explanatory approach, and a secondary data sampling technique was adopted. Statistics from the Philippines were obtained from the DOT library while Airbnb data was purchased from AirDNA last SeptemberNovember 2019. Secondary data collected were analyzed through SPSS. The study measured the relationship between Airbnb occupancy rates and tourist arrival. Moreover, to test whether Airbnb is directly competing with the lower category of hotel in terms of occupancy rates, the correlational examination was taken into account. Pearson $\mathrm{R}$ coefficient was utilized followed by a regression analysis to come up with a model. The findings inferred that it is Airbnb that has most influenced the activity of the tourism industry sector most especially under the accommodation sector and apparently set up to be a threat to the budget traditional providers. The result of the examination required for a business reaction for the traditional providers on the best way to team up with Airbnb to give better accommodation preferences for the increasing number of travelers in the country.
\end{abstract}

Keywords:

Airbnb, Economy Class Hotel, Occupancy Rates, Sharing Economy, Philippines, Tourist Arrival 


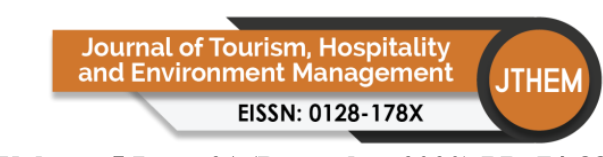

Volume 5 Issue 21 (December 2020) PP. 74-88

\section{Introduction}

DOI 10/35631/JTHEM.521005

The tourism industry incorporates a wide scope of activities but one of the most important in the package of services a tourist requires is accommodation (Aznar et al., 2016). Accommodation industry is the most important segment of tourism industry (Banerjee, 2014). Tourism has been considered one of the main sources of economic development for both developed and developing countries. Tourists benefit from the improvement and extended test made possible by the advancement of the sharing economy.

Airbnb website claimed itself as "a trusted community marketplace for people to list, discover, and book unique accommodations around the world" and it instantiates a peer-to-peer marketplace in the sharing economy (Airbnb, 2018). According to their site (2019), since its establishment in 2008, Airbnb became one of the largest online accommodation providers and an epitome of sharing economy. It offers for rent more than 7 million homes, apartments and condominiums in almost all countries (Adamiak, 2019).

Several scholars have identified the competition between hotels and Airbnb platform. In a recent study of Sainaghi \& Baggio, (2020) they analyzed the possible substitution threats between Airbnb listings and hotels. The hotel sector is particularly vulnerable against the vital disruption introduced by sharing platforms as embodied by the threat of Airbnb (Akbar and Tracogna,2018). Previous studies showed that budget hotels are significantly more impacted by Airbnb than luxury hotels (Quynh, 2014). Congruent to the case study made by Manchester, (2017) his findings suggest that Airbnb is a disruptive innovation for the lower and mid portions of the hotel industry, yet disruption is not occurring in the higher portion. Airbnb was relied upon to beat budget hotels (Guttentag and Smith, 2017; Zervas et al., 2017). Pricing strategies and unique experiences that Airbnb offers to travelers are some of the factors why tourists are substituting Airbnb over hotels (Oskam and Boswijk, 2016). In fact, Hotel managers in Istanbul believed that they were losing some business to Airbnb, yet they generally neither perceive Airbnb as a genuine threat nor were they for the most part taking concrete vital measures to react to Airbnb (Alrawadieh, et al., 2020). The present study was keen to determine if the results would be identical from the outcome aforementioned, given that Airbnb entered the Philippine market eight (8) years ago.

However, according to the company, there is a range of benefits associated with the sharing economy, including positive social and environmental impacts. For hosts, the economic benefit of Airbnb is often life-changing, and for cities, it is revitalizing for neighborhoods and small businesses alike. The economic benefits of home-sharing are distributed across at least three categories: 1.) Positive impacts on consumers and the tourism industry, 2.) Positive impacts on neighborhoods and local businesses, and 3.) Positive impacts on residents and households (Airbnb, 2018).

For an archipelagic country like Philippines, that is blessed with unique natural wonders, tourism industry is a vital sector for the economy. Accommodation is a base of tourism industry as it forms the tourist intention to travel in one destination (Poudel, 2013). Currently, there is a knowledge gap in the literature about Airbnb's presence in the Philippines and its impact on economy class hotels. The study responds to calls by several scholars for more research addressing the impact of Airbnb to traditional accommodation services. This study does so with a specific focus on the economy class hotels - the lowest category of hotel in the country, which some studies suggest may be particularly vulnerable to Airbnb competition. Also, the 


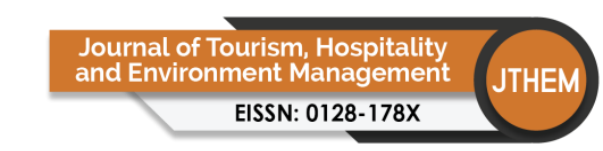

Volume 5 Issue 21 (December 2020) PP. 74-88 DOI 10/35631/JTHEM.521005

limited research addressing Airbnb's perceived impacts on traditional lodging has been conducted in developing country, so the topic remains largely neglected in developing country like Philippines. This study focused on Metro Manila as it is the capital of the country. Moreover, the area paid attention to seven (7) selected cities namely: Makati, Mandaluyong, Manila, Parañaque, Pasay, Pasig and Quezon city. Chosen cities possessed readily available data in AirDNA needed for study.

This study aimed to contribute to the insufficient study about Airbnb listings in the Philippines and provide additional information not only to potential Airbnb entrepreneurs but also to Philippine government agencies. Studies about hotel competition by Airbnb in other countries was a good deal of, however, as to date, there is no study that focused on the competition that has caused by Airbnb into the hotel industry. Likewise, the study also aimed to scrutinize the impact of Airbnb in the Philippine setting by measuring its performance with regards to occupancy rates, as it is one of the main key performance indicators of success in any accommodation establishments. Given that Airbnb entered the Philippine market eight years ago, only three studies were conducted in the country, this study wants to advance the knowledge of the readers by sharing the impact that has caused by Airbnb in the country based on the available data from Department of Tourism (DOT) library and website and AirDNA - a paid service tool specialize in Airbnb data.

This study also acknowledged the statement that there is an urgent need for a competitive mapping of the space occupied by the various hotel categories and Airbnb, due to the inability of quantitative research thus far to agree on Airbnb's exact impact on the hotel industry in general (Koh and King, 2017). The more extensive point was to make a functional contribution to the current discussions and issues around the sharing accommodation, in particular Airbnb platform, from ethnically diverse country standpoint.

\section{Literature Review}

\section{Airbnb As Part of The Sharing Economy}

A handful of studies have identified Airbnb as a sharing economy. For example, Airbnb is an online network commercial marketplace empowering transient rentals running from shared spaces to whole homes that have now contributed in excess of ten million overall appointments to the supposed sharing economy (Zervas et al., 2015a). Online platforms as Airbnb are normally described under something many refer to as the "Sharing Economy", a category that darkens their actual nature (Oskam and Boswijk, 2016).

The topic "Airbnb" is the prevailing subject with different ideas mirroring the effect including host-guest relationships, individuals' utilization of their homes, host-guest connections, impacts on the properties, local people, short-term rental market, lodging, payment concerning tax, owners, and guest's length of stay just as well as competition with the traditional accommodation sector. The outcomes demonstrate that the Sharing Economy is a billion-dollar field. The idea additionally demonstrates the hazardous development of the Shared Economy that prompts worldwide social changes, especially with the Sharing Economy's commitments to sustainable consumption practices and innovation in Tourism Hospitality (Cheng and Edwards, 2019). 


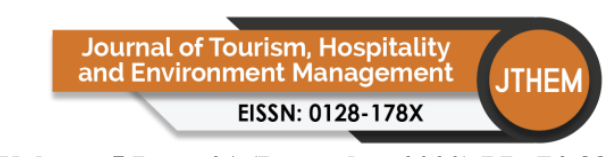

Volume 5 Issue 21 (December 2020) PP. 74-88 DOI 10/35631/JTHEM.521005

Airbnb can be a significant source of income, but hosts' ability to generate it consistently depends to a large degree on how frequently and at what price they are able to attract bookings from potential guests (Jhaver, Karpfen, \& Antin, 2018). Airbnb likewise permits Airbnb hosts the capacity to turn a profit locally, rather it is for additional spending money or as a sole income (Johnson, 2015). More and more people are now connecting through the sharing economy platforms to supplement their income or to save money (Dillahunt and Malone, 2015).

\section{Airbnb Effect on Tourism/Tourist}

Tourist accommodation is a widely investigated topic as it represents a major contribution to the total tourist expenditure (Masiero et al., 2015). Some studies connect tourist arrivals in different variables such as the study of Nepal et al., (2019), it showed that a $1 \%$ increase in Gross Domestic Product increases tourist arrivals by $1.56 \%$. Another study concluded that the more tourist arrivals in a given year reduce the probability that the country will be in conflict in the subsequent year (Becken and Carmignani, 2016). However, little attention has been dedicated to the relation between tourist arrivals and performance indicators (Chen, 2016) with the exception of the study of Ginindza and Tichaawa, (2019), that foreign visitor arrivals revealed a coefficient of 0.154 indicating the existence of a positive but weak relationship between the hotel room occupancy rate and foreign visitor arrivals (Ginindza and Tichaawa, 2019).

This study was anchored with the study of Yen (2016), who affirmed that the majority of the economic impact comes from spending on tourism accommodation services. According to Makochekanwa (2013), tourism is an important sector in most Southern African Development Community (SADC) countries. As found in his study, the tourism sector contributes meaningfully to individual regional economies in terms of GDP, employment, export receipts, and investment.

Peer-to-peer accommodation sharing economy services such as Airbnb have had impacts on the accommodation industry (Zervas et al., 2015b). One advantage of sharing economy for destinations and local residents include longer tourist stays at destinations with more affordable accommodation, thus empowering tourists to spend more money at the destination, which contributes to the economy of the destination, and permitting local residents to earn money from their unused resources (Haywood et al., 2017). In Turkey, the tourism accommodation sector has a direct impact on the growth performance of the Turkish Economy (Harun, AKÇA, \& Bayraktar, 2016). In Iran, the tourism industry is a significant source of income and influences the economy of both the host and source and nations. The tourism industry brings in large amounts of income into a local economy in exchange for products and services needed by tourists (Feili et al., 2017).

In the Philippines, Tourism sector was still essential that drives the country's economic growth (Rivera and Gutierrez, 2019). While according to Remo (2018), in his report in Philippine Daily Inquirer, local travel and tourism industry remained a splendid spot for the Philippine economy and the land business. In 2017, the travel and tourism accommodation sector contributed a sum of P3.35 trillion to the Philippine economy, representing around $21 \%$ of the nation's (GDP), as indicated by the most recent report from the World Travel and Tourism Council (para. 2). 


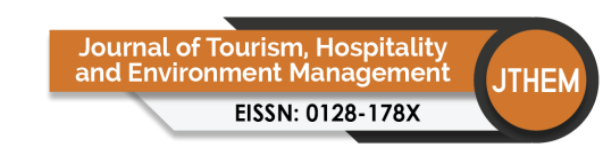

Volume 5 Issue 21 (December 2020) PP. 74-88 DOI 10/35631/JTHEM.521005

In 2017, the tourism industries contributed $12.2 \%$ to the economy. It is measured by the share of Tourism Direct Gross Value Added (TDGVA) to the Gross Domestic Product (GDP). The TDGVA amounted to Php 1,929.3 billion at current prices in 2017. This is higher by $24.2 \%$ than the previous year's record of PhP 1,553.7 billion (Philippine Tourism Satellite Accounts, 2018).

Additionally, in Barcelona the relation between accommodation places and the resident population shows that new residential areas are being added to the traditional areas of strong pressure from tourism along the city's main tourist axis, and Airbnb clearly contributes to that pressure (Gutierrez et al., 2016). Airbnb creates new job positions as more travelers visits the destination because of lower convenience costs (Fang et al., 2016). The utilization of tourists of a few products and services in this manner raises the gross national product of the destination. The tourists must go to the destination territory to expend the tourism industry offering. The tourism industry offering is basically an assistance that must be at the same time delivered and consumed by the tourist. This makes adequate open doors for value adding at the destination (Apleni, Vallabh \& Henama, 2017).

According to Guttentag, (2015) staying with Airbnb leads numerous tourists to increase their length of stay at a destination, implying that Airbnb leads to additional visitations. In the study of Chen (2016), both the OLS and quantile regression estimation results indicated a consistent and significant effect of growth rate of tourist arrivals on growth rate of sales in terms of performance such as occupancy rates.

As per Colliers, reported by Bondoc (2017), notwithstanding the continuous increase in international arrivals, the hotel average occupancy across Metro Manila declined possibly from $70 \%$ in 2017 to $69 \%$ in 2018 . The figure moved toward the upper-end of their occupancy conjecture of $65 \%$ to $68 \%$ for 2018 . While a majority of the short-term rental platforms have begun to make their significance over the last decade, it is Airbnb that has most influenced the activity of the tourism industry sector most especially under the accommodation sector and apparently set up the most grounded competition or threat to the traditional providers of the hotel industry as proven by some of the research works of (Guttentag and Smith, 2017; Zervas et al., 2017; and Boros, et al., 2018). In light of the investigation, Airbnb has and will keep on infringing on the business of the traditional accommodation services.

\section{Occupancy Rate}

Since the researcher is a hospitality academician by profession the researcher then used the definition from Philippine Statistics Authority which is Average occupancy rate - is the ratio of the number of occupied rooms to the number of available rooms. In academics, it is computed by the following formula:

\section{Occupancy rates $=$ Rooms Sold/Rooms Available*100}

As revealed by Jeffrey et al., (2002), occupancy rate was the only widely available, consistent, and temporally dis-aggregated means of monitoring hotel performance at the individual hotel level across the industry. It also empowered the identification of trends and fluctuations within the industry (O'Neill, 2011) as cited in the study of (Lei and Lam 2015). Because of these considerations, the occupancy rate was used in this research to illustrate the performance of Airbnb and Economy class hotels in the country. 


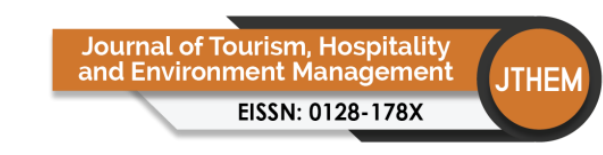

Volume 5 Issue 21 (December 2020) PP. 74-88 DOI 10/35631/JTHEM.521005

The effect of Airbnb on the hotel business industry has materialized negligibly in a decrease in occupancy rates (Ytreberg, 2016). In contrast, ever since Airbnb entered the lodging scene in 2008 , the hotel industry has cast a wary eye, noting its popularity with young travelers. Despite a strong year for hotels - occupancy rates broke records in 2015, according to the data from Smith Travel Research (STR).

In the study of Goree (2016) in US, it was resulted in to two distinction. Airbnb's entrance into the lodging industry did not have a significant impact on hotel occupancy rates in San Francisco from 2008 to 2014. However, the results suggest that the company's rise may have had a significant impact on hotel occupancy rates in Chicago during the same time period. Her investigation from San Francisco has demonstrated that Airbnb insignificantly affects the hotels' occupancy rates and a marginally significant negative effect on Chicago hotels' occupancy rates. Business travelers are not supplanting Airbnb over hotel industry due to Airbnb's nonappearance of extravagances that numerous business travelers request, and the nonattendance of an Airbnb loyalty program (Goree, 2016).

In the study of Quynh, (2014) its results showed that Airbnb reservations grow even when hotel occupancy increases. This is supported by Ginindza and Tichaawa's, (2019) study, that the Airbnb sharing accommodation platform do not have a statistically significant negative impact on the hotel occupancy rates in Swaziland. Moreover, according to the research findings of Zervas et al. (2015) and Guttentag (2015), a negative relationship exists between sharing accommodation and hotel performance, with the relationship in occupancy rates.

The recent study was eager to analyze the impact of Airbnb into economy class hotels' occupancy rates; thus, the study measure its performance to know whether Airbnb has a direct impact on economy class hotels in the country.

\section{Methodology}

The study measured the relationship between Airbnb occupancy rates and tourist arrival in the selected cities in Metro Manila. Moreover, to test whether Airbnb is directly competing with lower category of hotel in terms of occupancy rates, correlational examination was taken into account. Discoveries from correlational examination can be utilized to determine the relationships among variables, and to forecast functions from knowledge and current information (Curtis et al., 2016).

Data was obtained from DOT library while Airbnb data was purchased from AirDNA last September-November of 2019. Secondary data collected were analyzed through SPSS. With the use of panel data on the monthly tourist arrival in the Philippines, economy hotels' occupancy rates and the number of Airbnb room occupancy rate in Metro Manila for the periods of 2016-2018, respectively, the study applied Pearson R correlation and hierarchical regression model to respond to the research questions. To determine relationships between variables, and if a relationship exists, determine a regression equation that could be used make predictions to a population are the primary purpose of a correlational study (Simon and Goes, 2011). This study was purely confirmatory in nature. Since the study focused on correlation and regression, inferential statistics was utilized in analyzing data. 
This study focused on specific research questions:

$R Q 1$ : What is the significant relationship between economy hotels occupancy rates and Airbnb occupancy rates?

$R Q 2$ : What is the significant relationship between economy hotel occupancy rates and tourist arrivals?

RQ3: What is the significant relationship between Airbnb occupancy rates and tourist arrivals?

\section{Hypotheses}

Based on the previous research questions the following hypotheses were tested:

Ho1: There is no significant relationship between economy hotel occupancy rates and Airbnb occupancy rates.

Ho2: There is no significant relationship between economy hotel occupancy rates and tourist arrivals.

Ho3: There is no significant relationship between Airbnb occupancy rates and tourist arrivals.

\section{Results and Discussions}

In presenting the results, the researcher made use of the scatterplot. The advantage of the scatterplot is that it is simple to construct, is non-mathematical in nature and is unaffected by any extreme values that may be present in the data set. It also tells us immediately if there are outliers or if the relationship is actually non-linear or not entirely linear. A line is usually drawn through the points on a scatter plot to identify linearity in the relationship. This line is called the regression line or the least squares line, because it is determined such that the sum of the squared distances of all the data points from the line is the lowest possible (Gogtay and Thatte, 2017).

RQ1: What is the significant relationship between economy hotels occupancy rates and Airbnb occupancy rates?

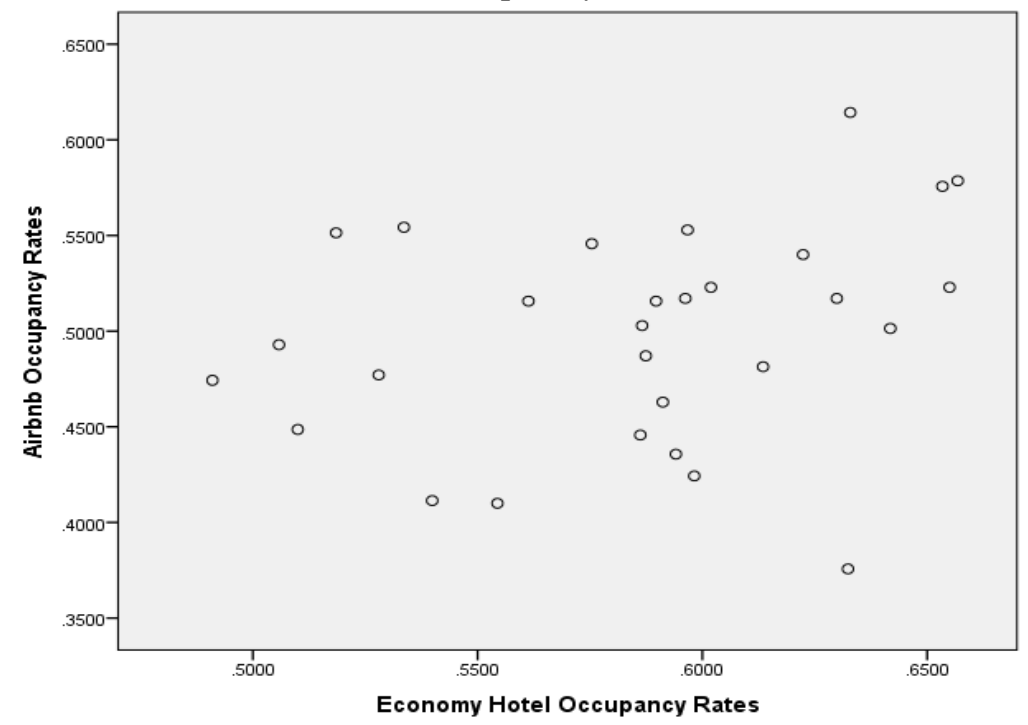

Figure 1. Relationship between Economy class Hotel Occupancy Rates and Airbnb Occupancy Rates using Scatter plot 
Volume 5 Issue 21 (December 2020) PP. 74-88 DOI 10/35631/JTHEM.521005

For Economy class Hotel Occupancy Rates and Airbnb Occupancy Rates, the graph in figure 1 tells us that there is somewhat positive linear relationship. To better understand the correlation of both variables, the study took advantage of the scatter plot. A correlation analysis begins with the construction of a scatter plot or scatter diagram (a graphical representation of the data) with one variable on the X-axis and the other on the Y-axis (Gogtay and Thatte, 2017).

Table 1. Relationship using Pearson R Correlation Coefficient

\begin{tabular}{l|l|l|l}
\hline Statistical Test & Value & P-value & Interpretation \\
\hline $\begin{array}{l}\text { Pearson R Correlation } \\
\text { Coefficient }\end{array}$ & 0.283 & $0.137^{*}$ & $\begin{array}{l}\text { There is no significant } \\
\text { linear relationship }\end{array}$ \\
\hline
\end{tabular}

*Significant if $P$-value $<0.05$ level of significance

Table 1 supported the graph in figure 1 by looking at the value of the Pearson $\mathrm{R}$ Correlation Coefficient. The Pearson's correlation coefficient establishes a relationship between the two variables (Gogtay and Thatte, 2017). As shown in the table there is only $28.3 \%$ of linear relationship between the variables and the $\mathrm{P}$-value was 0.137 which was greater than 0.05 level of significance. Which means that there is no significant linear relationship between economy hotel occupancy rates and Airbnb occupancy rates. Therefore: Ho1 was accepted.

The findings showed that both parties vary in number of rooms available and number of rooms sold with respect to their occupancy rates, wherefore, both parties may not be seen as competitors. This can be concluded that Airbnb and Economy class hotel caters different market and that they offer different price range, in the same manner as Adamiak (2019), viewed Airbnb as it markets a diverse range of peer-to-peer and commercial services.

Further, the results showed a distinction with Miller, (2016) as cited by (Wright, 2017), that states that Hotel industry leaders aggressively resisted Airbnb's presence as a new market competitor and called for stricter regulations against Airbnb to eliminate any unfair competitive advantage.

RQ2: What is the significant relationship between economy hotel occupancy rates and tourist arrivals?

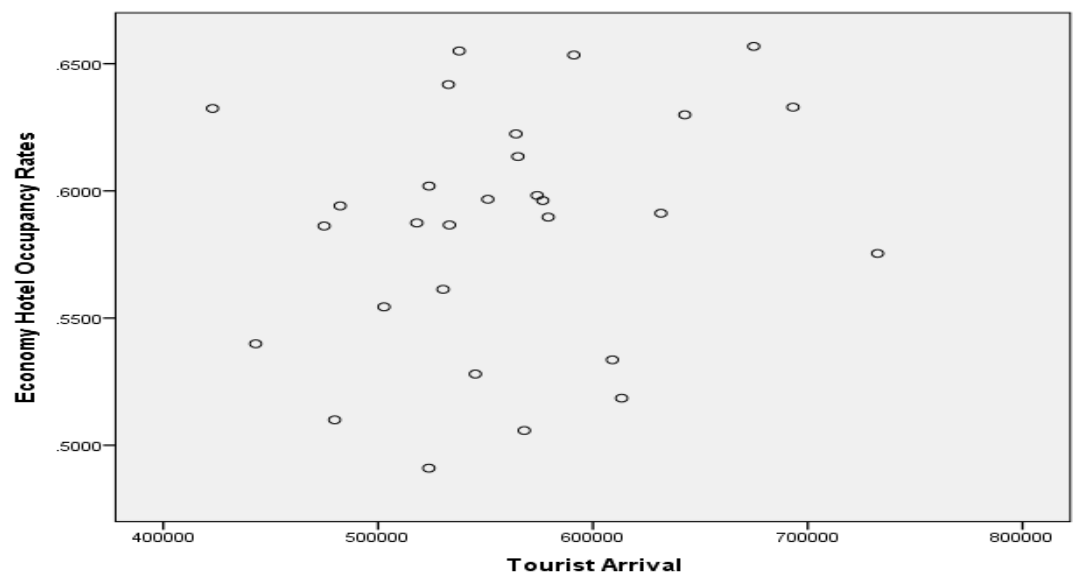

Figure 2. Relationship between Tourist Arrival and Economy Hotel Occupancy Rates using Scatterplot 
For Tourist Arrival and Economy class Hotel Occupancy Rate, it seems to be a quite positive linear relationship since the data were dispersed as resulted in figure 2.

Table 2. Relationship using Pearson R Correlation Coefficient

\begin{tabular}{l|l|l|l}
\hline Statistical Test & Value & P-value & Interpretation \\
\hline $\begin{array}{l}\text { Pearson R Correlation } \\
\text { Coefficient }\end{array}$ & 0.213 & $0.268^{*}$ & $\begin{array}{l}\text { There is no significant } \\
\text { linear relationship }\end{array}$ \\
\hline
\end{tabular}

*Significant if P-value $<0.05$ level of significance

Table 2 supported the graph in figure 2 by looking at the value of the Pearson R Correlation Coefficient. There is only $21.3 \%$ of linear relationship between the variables and the P-value was 0.268 which was greater than 0.05 level of significance. Therefore: Ho2: was accepted. Hence, an increase in number of tourist arrival does not imply a raise of demand on the number of economy class hotel rooms. Contrasted the study of Lei and Lam, (2015) that concluded that an increase in number of tourist arrival in Macao raised the demand on the number of hotel rooms.

The data consequently resulted in a quite positive relationship between the number of tourist arrivals and Economy class hotels occupancy rate. The findings perceived a disparity with the study that affirmed that there is an existence of a positive but weak relationship between the hotel room occupancy rate and foreign visitor arrivals (Ginindza and Tichaawa, 2019).

However, findings also implied that number of tourist arrival is somewhat significant in anticipating hotel's rate of occupancy. The outcome corresponds to (Purwomarwanto and Ramachandran, 2015), which concluded that the number of international tourist arrivals is significant for predicting hotel's occupancy rate in Malaysia, Singapore and Indonesia.

RQ3: What is the significant relationship between Airbnb occupancy rates and tourist arrivals?

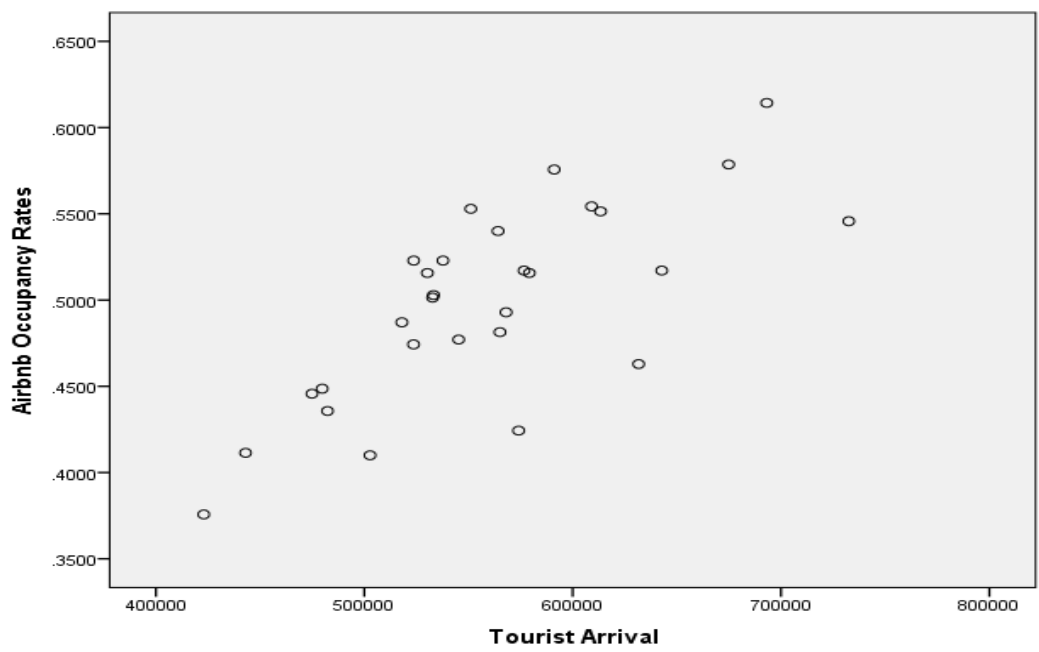

Figure 3. Relationship between Tourist Arrival and Airbnb Occupancy Rates using Scatterplot 
Looking at the scatterplot in figure 3, it suspect a strong direct relationship between Tourist Arrival and Airbnb Occupancy Rates. Based on this, it was observed that the increase of Tourist Arrival may increase the Airbnb Occupancy Rates.

Table 3. Relationship using Pearson R Correlation Coefficient

\begin{tabular}{l|l|l|l}
\hline Statistical Test & Value & P-value & Interpretation \\
\hline $\begin{array}{l}\text { Pearson } \\
\begin{array}{l}\text { Correlation } \\
\text { Coefficient }\end{array}\end{array}$ & 0.743 & $\begin{array}{l}\text { There is a significant } \\
\text { linear relationship }\end{array}$ \\
\hline *Significant if P-value <0.05 level of significance & & \\
\hline
\end{tabular}

As shown in the above results in table 3 , there is a $74.3 \%$ of getting a positive linear relationship between the variables. Also, a P-value of 0.000 was calculated concluding that the relationship was significant at 0.05 level of significance. The implication of this positive linear relationship is that an increase in the number of tourist arrival was accompanied by an increase in the occupancy rates of the Airbnb listings. With this, Ho3: was rejected.

Accordingly, an increase in supply of Airbnb listings allowed more accommodation for tourist; while at the same time an increase in number of tourists raised the demand on the number of Airbnb listings and increased its occupancy rate. The results coincides in Barcelona, that the relation between accommodation places and the resident population shows that new residential areas are being added to the traditional areas of strong pressure from tourism along the city's main tourist axis, and Airbnb clearly contributes to that pressure (Gutierrez et al., 2016).

\section{Table 4. Performing Regression Analysis for Airbnb Occupancy Rate where Tourist} Arrival treated as an independent variable

\begin{tabular}{l|l|l|l|l}
\hline Variables & Beta Coefficient & Standard Error & P-value* & Interpretation \\
\hline Constant & 0.170 & 0.057 & 0.006 & Significant \\
\hline Tourist Arrival & 0.0000005872 & 0.000 & 0.000 & Significant \\
\hline
\end{tabular}

*Significant if P-value $<0.05$ level of significance

Since the investigation suspect a direct relationship between Tourist Arrival and Airbnb Occupancy Rate, it then performs a regression analysis to build a model. As observed in table 4, Tourist Arrival was found to be significant at 0.05 level of significance. Hence, it conveys the impression that an increase in Tourist Arrival may lead an increase of 0.0000005872 in the Airbnb Occupancy Rate. Thus, the regression model build was:

\section{Airbnb Occupancy Rate $=0.170+0.0000005872 *$ Tourist Arrival}

Notwithstanding the continuous increase in international arrivals in Metro Manila, as reported by Colliers, (2019). The findings inferred that it is Airbnb that has most influenced the activity of the tourism industry sector most especially under the accommodation sector and apparently set up to be a threat to the traditional providers of the hotel industry most especially economy class hotels as it the lowest category of hotel as proven by some of the research works of (Guttentag and Smith, 2017; Zervas et al., 2017; and Boros, et al., 2018). Nonetheless, this 


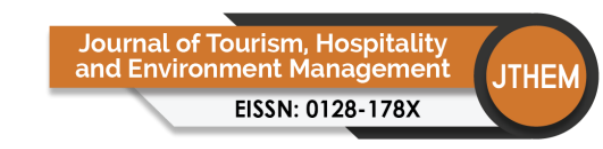

Volume 5 Issue 21 (December 2020) PP. 74-88 DOI 10/35631/JTHEM.521005

study need to take note that the absolute quantities of Airbnb listings in countries are reliant on the level of economic development and size of inbound tourism flow (Adamiak, 2019).

\section{Conclusion and Recommendations}

With respect to occupancy rates, both parties vary in number of rooms available and number of rooms sold, with that, the study concludes that Airbnb and Economy class hotel caters different market and that they offer a different price range and that both parties may be viewed as non-competitors. International tourist arrivals to the Philippines rose by $7.7 \%$ or 7.1 million visitors in 2018 compared to 2017 (DOT, 2019). Indeed, Airbnb's entrance into the hotel accommodation landscape, regardless of how the company positions itself, increased the available supply of rooms for accommodating travelers to a specific destination. It was also beneficial to the tourism accommodation industry and to the economy as they provide an additional accommodation preference for tourists and additional income for entrepreneurs that boosted the economy of the country.

However, since Airbnb and hotels both offer accommodation services for tourists, the study compared the two parties with regard to their occupancy rates. The investigation with regards to the relationship between tourist arrival and economy hotels' occupancy rate was not vital in Metro Manila. On the other hand, the exploration with regards to the relationship between tourist arrival and Airbnb's occupancy rate was essential, thus an increase in tourist arrival may lead an increase of 0.0000005872 in the Airbnb Occupancy Rate, with a regression model of:

\section{Airbnb Occupancy Rate $=0.170+0.0000005872 *$ Tourist Arrival}

The results of the study was identical from the previous studies who claimed that Airbnb platform apparently to beat low-priced accommodation services. Therefore, the findings inferred that Airbnb penetration will influence the activity of the tourism industry, most especially under the accommodation sector. This suggests that Airbnb and economy class hotels and the like may collaborate to sustain the continuous increase of tourist arrival in the upcoming years.

This study concludes that Airbnb is at the leading edge of travel in present time. Likewise, this study signified that Airbnb is a pioneer and will be a contributor to a new wave in the Philippine's accommodation sector. Furthermore, this platform can help young entrepreneurs and business people who have excess inventory such as their vacant condominium, apartment or even their whole house as they can rent it out to people looking for accommodations as an alternative to traditional hotels to make additional money.

The result of the examination required for a business reaction for the traditional providers on the best way to team up with Airbnb to give better accommodation preferences for the increasing number of travelers in the country. The perception that the growth of Airbnb was not seen as a threat to low priced accommodation establishments or services that offers cheaper than economy class hotels was a genuine misunderstanding if left unresponded.

Travelers today are looking for less expensive travel that have a lot of experiences that are more authentic and off the beaten path, this seems to be the reason why tourist are hooked on this type of platform. Philippines as the seventh most populous country in Asia and the fact that the country has a continuous increase of tourist arrival yearly this study want to advance the 


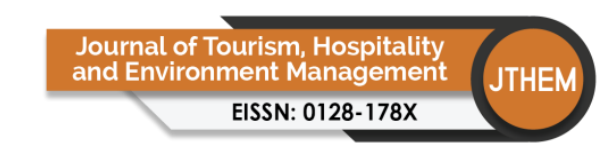

Volume 5 Issue 21 (December 2020) PP. 74-88 DOI 10/35631/JTHEM.521005

technology to make a deal between Airbnb and big businesses to tie-up for any upcoming big events in the country. The country need to stay steadfast and educate others, as well as correct other countries perceptions to see incredible changes and development in the tourism industry in the future. Lastly, this study believed that Airbnb is beyond room rentals, Airbnb expects to add an array of hospitality services as host turns into hoteliers by allowing tourist to rent their place.

\section{Directions for Future Research}

Several limitations possessed in this study and calls for further research to have a thorough mapping on the impact of Airbnb in the hotel industry. To start with, outcomes of the study must be exclusively applied to Philippine market and thus reached out to Metro Manila as this is the prime tourist destination in the Philippines. However, the market might exhibit the peculiarity that might diminish the generalizability of the findings of this paper. Broader studies of this type together with government agencies responsible for funding researchers due to costly data available using third party tool would help modify, confirm, and refine the findings in this paper through comparative analysis.

More so, future researchers may have desired other sharing economy platforms that offer accommodation services such as CouchSurfing and HomeAway which currently made names in the country. In addition, other key performance indicators could be deliberated for future researches (ie. RevPAR and Average Daily Rate) while other categories of accommodation services that offers lower prices than hotels in different areas in the Philippines could be likewise tackled (ie. pension houses, home stay and inns).

\section{References}

Adamiak, C. (2019). Current state and development of Airbnb accommodation offer in 167 countries. Current Issues in Tourism, 1-19.

Akbar, Y. H., \& Tracogna, A. (2018). The sharing economy and the future of the hotel industry: Transaction cost theory and platform economics. International Journal of Hospitality Management, 71, 91-101.

Airbnb (2018), "New study: Airbnb community generates $\$ 51$ million in economic impact in Boston", Airbnb, San Francisco, CA, 19 December, [Google Scholar]

Alrawadieh, Z., Guttentag, D., Cifci, M. A., \& Cetin, G. (2020). Budget and midrange hotel managers' perceptions of and responses to Airbnb. International Journal of Contemporary Hospitality Management.

Apleni, A., Vallabh, D. \& Henama, U.S. (2017). Motivation for tourist's participation in religious tourism in Eastern Cape: A case study of Buffalo City, South Africa. African Journal of Hospitality, Tourism and Leisure, 6 (2), 1-10.

Aznar, J. P., Sayeras, J. M., Galiana, J., \& Rocafort, A. (2016). Sustainability commitment, new competitors' presence, and hotel performance: the hotel industry in Barcelona. Sustainability, 8(8), 755.

Banerjee, D. (2014). Hospitality and Its Importance to the Tourism Industry: A Case Study on Selected Hotels in Kolkata. International Journal for Marketing Studies, 68-89.

Becken, S., \& Carmignani, F. (2016). Does tourism lead to peace?. Annals of Tourism Research, 61, 63-79.

Bondoc, (2017) Retrieved December 18, 2018 from: https://www.philstar.com/business/2017/12/25/1771734/philippines-needs-morehotelinvestments 


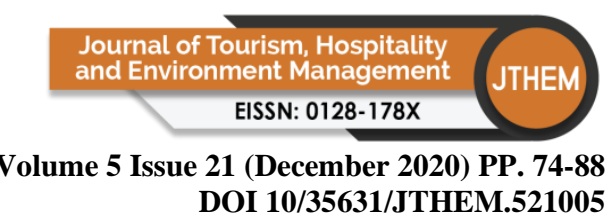

Boros, L., Dudás, G., Kovalcsik, T., Papp, S., \& Vida, G. (2018). Airbnb in Budapest: analysing spatial patterns and room of hotels and peer-to-peer accommodations. GeoJournal of Tourism and Geosites, 10(1), 26-38.

Calinao, R. J., Atenta, N. A. A., \& Rioflorido, N. S. Entrepreneurial Motivations of the Airbnb Business in Makati City.

Chen, M. H. (2016). A quantile regression analysis of tourism market growth effect on the hotel industry. International Journal of Hospitality Management, 52, 117-120.

Cheng, M., \& Edwards, D. (2019). A comparative automated content analysis approach on the review of the sharing economy discourse in tourism and hospitality. Current Issues in Tourism, 22(1), 35-49.

Chua, E. L., Chiu, J. L., \& Bool, N. C. (2019). Sharing Economy: An Analysis of Airbnb Business Model and the Factors that Influence Consumer Adoption. Review of Integrative Business and Economics Research, 8, 19.

Colliers, 2019. Retrieved from: https://www2.colliers.com/en-PH/Research/ManilaMarket-Intelligence-July-9-201 9

Curtis, E. A., Comiskey, C., \& Dempsey, O. (2016). Importance and use of correlational research. Nurse researcher, 23(6).

Department of Tourism, (2019), Retrieved from: http://www.tourism.gov.ph/industry_performance_dec_2017.aspx

Dillahunt, T. R., \& Malone, A. R. (2015, April). The promise of the sharing economy among disadvantaged communities. In Proceedings of the 33rd Annual ACM Conference on Human Factors in Computing Systems (pp. 2285-2294).

Fang B, Ye Q, \& Law R (2016) Effect of sharing economy on tourism industry employment. Annals of Tourism Research 57: 234-278.

Feili, Hamid Reza \& Qomi, Mojtaba \& Sheibani, Sajedeh \& Azmoun, Ghazaleh. (2017). SWOT Analysis for Sustainable Tourism Development Strategies using Fuzzy Logic.

Ginindza, S., \& Tichaawa, T. M. (2019). The impact of sharing accommodation on the hotel occupancy rate in the kingdom of Swaziland. Current Issues in Tourism, 22(16), 19751991.

Gogtay, N. J., \& Thatte, U. M. (2017). Principles of correlation analysis. Journal of the Association of Physicians of India, 65(3), 78-81.

Goree, Katherine, "Battle of the Beds: The Economic Impact of Airbnb on the Hotel Industry in Chicago and San Francisco" (2016).

Gutierrez, J., Garcia-Palomares, J. C., Romanillos, G., \& Salas-Olmedo, $\quad$ M. $\quad$ H. (2016). Airbnb in tourist cities: comparing spatial patterns of hotels and peer-to-peer accommodation. arXiv preprint. arXiv preprint arXiv:1606.07138.

Guttentag, D. (2015). Airbnb: disruptive innovation and the rise of an informal tourism accommodation sector. Current issues in Tourism, 18(12), 1192-1217.

Guttentag, D. A., \& Smith, S. L. (2017). Assessing Airbnb as a disruptive innovation relative to hotels: Substitution and comparative performance expectations.

International Journal of Hospitality Management, 64, 1-10

Harun, B. A. L., AKÇA, E. E., \& Bayraktar, M. (2016). The contribution of tourism to economic growth: a research on the Turkey. Akademik Yaklaşımlar Dergisi, 7(1), 120.

Haywood, J., Mayock, P., Freitag, J., Owoo, K. A., \& Fiorilla, B. (2017). Airbnb \& hotel performance. STR publication. 


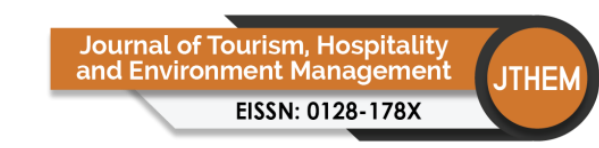

Volume 5 Issue 21 (December 2020) PP. 74-88 DOI 10/35631/JTHEM.521005

Jeffrey, D., Barden, R. R., Buckley, P. J., \& Hubbard, N. J. (2002). What makes for a successful hotel? Insights on hotel management following 15 years of hotel occupancy analysis in England. Service Industries Journal, 22(2), 73-88.

Jhaver, S., Karpfen, Y., \& Antin, J. (2018). Algorithmic Anxiety and Coping Strategies of Airbnb Hosts. Proceedings of the 2018 CHI Conference on Human Factors in Computing Systems - CHI '18. doi:10.1145/3173574.3173995

Johnson, M. (2015). Investing in Resting: Is Airbnb a Top 2016 IPO Candidate. Nasdaq. Hentet fra http://www. nasdaq. com/article/investing-inrestingis-airbnb-a-top-2016-ipo-candidate-cm553817\#ixzz4OCLu5CEX

Koh, E., \& King, B. (2017). Accommodating the sharing revolution: a qualitative evaluation of the impact of Airbnb on Singapore's budget hotels. Tourism recreation research, 42(4), 409-421.

Lei, W. S. C., \& Lam, C. C. C. (2015). Determinants of hotel occupancy rate in a Chinese gaming destination. Journal of Hospitality and Tourism Management, 22, 1-9.

Makochekanwa, A. (2013). An analysis of tourism contribution to economic growth in SADC countries. Botswana Journal of economics, 11(15).

Manchester, E. A. (2017). Sharing economy-disrupting established industries: A case study of Airbnb disrupting the hotel industry (Bachelor's thesis).

Masiero, L., Nicolau, J. L., \& Law, R. (2015). A demand-driven analysis of tourist accommodation price: A quantile regression of room bookings. International Journal of Hospitality Management, 50, 1-8.

Mendoza, J. V. B., Aquino, J. M. F., Briones, K. M., Geralde, J. M. C., Macasaet, J. M. G., Mirambil, A. R. S., \& Meñez, M. F. L. (2018). Determinant Factors of Airbnb Occupancy Rate in the Province of Batangas, Philippines. Journal of Tourism and Hospitality Research, 15(1).

Miller, S. R. (2016). Decentralized, Disruptive, and On Demand: Opportunities forLocal Government in the Sharing Economy. Ohio St. LJ Furthermore, 77, 47.

Nepal, R., al Irsyad, M. I., \& Nepal, S. K. (2019). Tourist arrivals, energy consumption and pollutant emissions in a developing economy-implications for sustainable tourism. Tourism Management, 72, 145-154.

O'Neill, J. W. (2011). Hotel occupancy: Is the three-year stabilization assumption justified?. Cornell Hospitality Quarterly, 52(2), 176-180.

Oskam, J., \& Boswijk, A. (2016). Airbnb: the future of networked hospitality businesses. Journal of Tourism Futures, 2(1), 22-42.

Philippine Statistics Authority, (2018). Retrieved December 18, 2018 from:https://psa.gov.ph/content/contribution-tourism-economy-122percent-2017

Poudel, S. (2013). The influence of the accommodation sector on tourism development and its sustainability: Case Study: Strand Camping, Larsmo.

Purwomarwanto, Y. L., \& Ramachandran, J. (2015). Performance of tourism sector with regard to the global crisis-a comparative study between Indonesia, Malaysia and Singapore. The Journal of Developing Areas, 325-339.

Quynh, N. "A Study of Airbnb as a Potential Competitor of the Hotel Industry" (2014).UNLV Theses, Dissertations, Professional Papers, and Capstones. 2618. https://digitalscholarship.unlv.edu/thesesdissertations/2618

Remo, A. R. (2018). Tourism still a bright spot for PH. Inquirer. net. https://business.inquirer.net/249613/tourism-still-bright-spot-ph

Retrieved from: 
Volume 5 Issue 21 (December 2020) PP. 74-88 DOI 10/35631/JTHEM.521005

Rivera, J. P. R., \& Gutierrez, E. L. M. (2019). A framework toward sustainable ecotourism value chain in the Philippines. Journal of Quality Assurance in Hospitality \& Tourism, 20(2), 123-142.

Sainaghi, R., \& Baggio, R. (2020). Substitution threat between Airbnb and hotels: Myth or reality?. Annals of Tourism Research, 83, 102959.

Simon, M. K., \& Goes, J. (2011). Correlational research. Includes excerpts from Simon. Available in: http://dissertationrecipes. com/wpcontent/uploads/2011/04/Correlational-ResearchX. pdf.

Wright, E. (2017). Airbnb: The Household Name Becoming the New Kid on the Tax Block. U. Louisville L. Rev., 56, 279.

Yen, D. (2016). AN ECONOMIC IMPACT STUDY OF A CONVENTION CENTER IN NORTHERN CALIFORNIA. [Google Scholar]

Ytreberg, N. S. (2016). Competitive effects of Airbnb on the Norwegian hotel market (Master's thesis, The University of Bergen).

Zervas, G., Proserpio, D., \& Byers, J. (2015a). A first look at online reputation on Airbnb, where every stay is above average. Where Every Stay is Above Average (January 28, 2015).

Zervas, G., Proserpio, D., \& Byers, J. W. (2015b). The impact of the sharing economy on the hotel industry: Evidence from Airbnb's entry into the Texas market. In Proceedings of the Sixteenth ACM Conference on Economics and Computation (pp. 637-637).

Zervas, G., Proserpio, D., \& Byers, J. W. (2017). The rise of the sharing economy: Estimating the impact of Airbnb on the hotel industry. Journal of marketing research, 54(5), 687-705. 